\title{
Tumor fibroso solitario intraoral: análisis clinicopatológico e inmunohistoquímico
}

\author{
Intraoral solitary fibrous tumor: clinical, pathologic, \\ and immunohistochemical analysis
}

\author{
J.A. García de Marcos' J.L. del Castillo Pardo de Vera², S. Arroyo Rodríguez³, M. Galdeano Arenas', \\ J. Calderón Polanco ${ }^{4}$, M.J. García de Marcos 5 , J. Valer Corellano 6
}

Resumen: El tumor fibroso solitario (TFS) es una neoplasia de partes blandas compuesta por células fusiformes, que principalmente se origina en las superficies mesoteliales. Generalmente tiene una localización intratorácica y la afectación de la cavidad oral es excepcional. Clínicamente el TFS intraoral suele presentarse como una masa móvil, submucosa, no dolorosa, bien circunscrita, de lento crecimiento. El diagnóstico se obtiene mediante al análisis histopatológico e inmunohistoquímico. Histológicamente se caracteriza por una disposición variable de células fusiformes ovoides, generalmente positivas para el marcador CD34. El tratamiento de elección es la extirpación quirúrgica de la lesión, recomendándose un seguimiento postoperatorio a largo plazo por la posibilidad de aparición de recurrencias y metástasis tardías.

Presentamos un caso de TFS intraoral, localizado en el fondo del vestíbulo mandibular. Un año después de la resección quirúrgica de la lesión, no hay signos de recidiva local o regional. Asimismo, realizamos una revisión de la literatura.

Palabras clave: Tumor fibroso solitario; Intraoral; Inmunohistoquímica; CD34.

Recibido: 07.12.2007

Aceptado: 07.03.2008

1 Especialista en Cirugía Oral y Maxilofacial. Servicio de Cirugía Oral y Maxilofacial. Complejo Hospitalario Universitario de Albacete. Albacete, España.

2 Especialista en Cirugía Oral y Maxilofacial. Servicio de Cirugía Oral y Maxilofacial. Hospital Universitario "La Paz". Madrid. España.

3 Especialista en Cirugía Oral y Maxilofacial. Jefe de sección del Servicio de Cirugía Oral y Maxilofacial. Complejo Hospitalario Universitario de Albacete. Albacete, España.

4 Especialista en Cirugía Oral y Maxilofacial. Jefe de Servicio de Cirugía Oral y Maxilofacial. Complejo Hospitalario Universitario de Albacete. Albacete, España.

5 Especialista en Estomatología. Práctica Privada. Madrid, España.

6 Especialista en Anatomía Patológica. Complejo Hospitalario Universitario de Albacete. Albacete, España.

Correspondencia:

J.A. García de Marcos.

C/ Antonio Acuña. № $105^{\circ} \mathrm{A}$ izq.

28009 Madrid, España.

Email: pepio2@hotmail.com

\begin{abstract}
Solitary fibrous tumors (SFT) are spindle cell neoplasms that most often originate from mesothelial lined surfaces. Intrathoracic tumors are more common and oral mucosal involvement is uncommon. Clinically, intraoral SFT is usually a painless, well delimited, slow-growing, mobile submucosal mass. Diagnosis is based on immunohistochemical and histopathologic analysis. Histologically, SFT is characterized by a variable provision of spindle cells, which generally are CD34-positive. Resection is the treatment of choice and long-term follow-up is recommended because recurrences and late metastases.

We present a case of intraoral SFT of the mandibular vestibular sulcus. One year after surgical resection, there were no signs of local or regional recurrence. The literature was reviewed.
\end{abstract}

Key words: Solitary fibrous tumors; Intraoral; Immunohistochemistry; CD34. 


\section{Introducción}

El tumor fibroso solitario (TFS) es una neoplasia rara de partes blandas, compuesta por células fusiformes, que generalmente se origina en las superficies mesoteliales, principalmente en la pleura..$^{1-6}$ Fue descrito por primera vez en 1931 por Klemperer y Rabin, ${ }^{7}$ como una lesión pleural. Se han utilizado otros nombres para describirlo, como mesotelioma fibroso localizado, tumor fibroso localizado, mesotelioma fibroso solitario, fibroma submesotelial y fibroma pleural. 1,5,12

Aunque el TFS suele localizarse en el tórax, se han descrito, casos en casi todas las localizaciones del organismo. . $-6,9,12,13^{-1}$ En cabeza y cuello se ha descrito en meninges, órbita, cavidad oral, nariz, senos paranasales, nasofaringe, espacio parafaringeo, laringe, en las tres glándulas salivares mayores, epiglotis, laringe, tiroides, piel, fosa infratemporal y tejidos blandos profundos cervicales. ${ }^{1-5,9,11,13}$ El TFS raramente aparece en la cavidad oral. ${ }^{1,3,8,10}$ Clínicamente, el TFS intraoral suele presentarse como una masa móvil, submucosa, no dolorosa, bien circunscrita, de lento crecimiento y de tamaño y evolución variable. ${ }^{1-4,8,11} \mathrm{El}$ color y la textura de la mucosa suprayacente suele ser normal.1,4 La superficie de la lesión es generalmente de color blanco y lisa. ${ }^{11}$ Clínicamente, el diagnóstico diferencial ha de realizarse con lipomas, fibromas, malformaciones vasculares, neoplasias de glándulas salivares, mucoceles, tumores de células granulares.3,4

El diagnóstico de TFS se obtiene mediante criterios distintivos microscópicos, que son variables y en ocasiones similares a otras lesiones, y mediante estudios inmunohistoquímicos..$^{1-3,8}$ Histológicamente se caracteriza por una disposición variable de células fusiformes, generalmente positivas para el marcador CD34. 2,4

El tratamiento del TFS consiste en la extirpación quirúrgica de la lesión. ${ }^{1-3,6,8,10-12}$ Todos los casos descritos en la literatura de TFS intraoral se han comportado de manera benigna, por lo que el pronóstico es muy bueno. ${ }^{2,3}$

\section{Caso clínico}

Paciente varón, de 37 años de edad, que acude a la consulta por presentar un nódulo paramandibular derecho, de 6 años de evolución, que en el último año ha aumentado de tamaño. Refiere que la lesión apareció tras la exodoncia de un molar inferior. ${ }^{46}$

A la exploración el paciente presentaba un nódulo de $1,5 \mathrm{~cm}$ de diámetro, en el fondo del vestíbulo, a la altura del 45 y del teórico 46. La lesión era móvil, bien delimitada, de consistencia elástica y dolorosa a la palpación. La mucosa suprayacente era normal. Se realizó una ortopantomografía en la que no se apreció patología mandibular. Bajo anestesia local se realizó la resección de la lesión, localizando previamente la salida del nervio mentoniano para preservarlo (Fig. 1). ${ }^{1}$ almost every location in the body. ${ }^{1-6,9,12,13}$ In the head and neck, SFT has been reported in the meninges, orbit, oral cavity, nose, paranasal sinuses, nasopharynx, parapharyngeal space, larynx, in the three major salivary glands, epiglottis, larynx, thyroid, skin, infratemporal fossa, and deep cervical soft tissues. 1-5,9,11,13 SFT rarely occurs in the oral cavity. 1,3,8,10 Clinically, intraoral SFT usually presents as a mobile, painless, well circumscribed, slow-growing submucosal mass of variable size and evolution. 1-4,8,11 The color and texture of the overlying mucosa usually is normal.1,4 The tumor surface is generally smooth and white. ${ }^{11}$ Clinically the differential diagnosis is made with lipoma, fibroma, vascular malformation, salivary gland neoplasm, mucocele, and granular cell tumor.3,4

SFT is diagnosed on the basis of distinctive microscopic criteria, which vary and sometimes are similar to other tumors, and by immunohistochemical studies. $1-3,8$ Histologically SFT is characterized by a variable disposition of spindle cells, which generally are positive for the CD34 marker. ${ }^{2,4}$

The treatment of SFT is surgical tumor resection. ${ }^{1-3,6,6,10-}$ ${ }^{12} \mathrm{All}$ the cases of intraoral SFT reported in the literature have behaved benignly, so the prognosis is good.2,3

\section{Clinical case}

A 37-year-old male patient consulted for a right paramandibular nodule, of 6 years' evolution, that had increased in size in the last year. He said that the tumor appeared after a lower molar was extracted. ${ }^{46}$

On examination, the patient had a nodule $1.5 \mathrm{~cm}$ in diameter in the vestibular sulcus, at the level of 45 and theoretical 46. The tumor was mobile, well delimited, of elastic consistency, and tender on palpation. The overlying mucosa was normal. Orthopantomography did not reveal mandibular pathology. 
Macroscópicamente se trataba de una lesión nodular, bien delimitada, blanquecina, de $2 \times 1,5 \times 1 \mathrm{~cm}$ de tamaño. Microscópicamente la lesión estaba formada por células uniformes fusiformes, con límites citoplasmáticos mal definidos, núcleos ovales o redondos, sin mitosis ni pleomorfismo nuclear. Las células se disponían al azar entremezcladas con fibras de colágeno y vasos sanguíneos aislados (Fig. 2). No había áreas de necrosis, ni patrón hemangiopericitoide. En la periferia la lesión estaba delimitada por un ribete de tejido conectivo.

Inmunohistoquimicamente las células de la lesión eran: intensamente positivas para: vimentina, CD34 y bcl2 (Fig. 3); débilmente positivas para: factor XIIla y actina músculo específica (1A4); y negativas para: proteina $S-100$, citoqueratinas (CAM 5,2;AE1-3), desmina y actina muscular (HHF35).

El postoperatorio evolucionó sin complicaciones, y tras un año de la cirugía no hay signos de recidiva local o regional.

\section{Discusión}

Inicialmente se creía que el origen del TFS estaba en las células mesoteliales o en los fibroblastos submesoteliales, ya que se trataba de una lesión que afectaba a la pleura visceral y a otras localizaciones serosas.3,11,12 Sin embargo, estudios inmunohistoquímicos, ultraestructurales y cultivos tisulares han demostrado que las células tumorales carecen de diferenciación mesotelial, y aunque la histogénesis del TFS es controvertida, se cree que puede tener un origen fibroblástico o miofibroblástico. 23,5,10-12 En concordancia con el origen mesenquimal está el hecho de que se haya documentado la aparición de este tumor en casi todas las localizaciones del organismo y que se hayan identificado tanto variantes malignas como benignas. 3,5

El origen histogénico está basado en una población específica de células fusiformes dendríticas intersticiales, CD34+, que están distribuidas por diferentes tejidos y órganos, incluido el tejido conectivo de la mucosa oral. ${ }^{1,3}$ Éstas son células mesenquimales primitivas que pueden funcionar como células presentadoras de antígeno o ejercer un papel en la reparación tisular. ${ }^{1}$

Shimoyama y cols. ${ }^{8}$ realizaron una revisión de todos los casos publicados de TFS oral, en revistas de lengua inglesa y japonesa hasta el año 2002, recogiendo únicamente 47 casos. La media de edad era de 51 años y existía un predominio por el sexo femenino (30:18). La localización yugal fue la zona de afectación predominante seguido en orden decreciente por la lengua, encía, pala-
The tumor was resected under local anesthesia after identifying the mental nerve tract to preserve it (Fig.1). ${ }^{1}$ Macrocospically, the tumor was nodular, well-delimited, whitish, and measured $2 \times 1.5 \times 1 \mathrm{~cm}$. Microscopical$l y$, the tumor was formed by spindle cells of uniform appearance with poorly defined cytoplasmic limits, oval or round nuclei, and no mitotic figures or nuclear pleomorphism. Cells were arrayed randomly and interspersed with collagen fibers and isolated blood vessels (Fig. 2). There were no areas of necrosis or a hemangiopericytoid pattern. On the periphery, the tumor was delimited by a margin of connective tissue.

Immunohistochemically, tumor cells were intensely positive for vimentin, CD34, and bcl2 (Fig. 3), weakly positive for factor XIIIa and muscle-specific actin (1A4), and negative for S-100 protein, cytokeratins (CAM 5,2; AE 1-3), desmin, and muscular actin (HHF35).

The postoperative period passed without complications and one year alter surgery there were no signs of local or regional recurrence.

\section{Discussion}

It was initially thought that the origin of SFT was in the mesothelial cells or submesothelial fibroblasts because the lesion affected the visceral pleura and other serosal locations. $3,11,12$ However, immunohistochemical and ultrastructural studies and tissue culture have demonstrated that the tumor cells lack mesothelial differentiation. Although the histogenesis of SFT is debated, it is believed that it may have a fibroblastic or myofibroblastic origin. $2,3,5,10-12$ A mesenchymal origin is consistent with the documented finding that this tumor occurs almost everywhere in the body and the fact that both malignant and benign variants have been identified. 3,5

The histogenic origin is a specific population of interstitial dendritic spindle cells, CD34+, that are distributed in dif- 
dar, labio, fondo de vestíbulo, trígono retromolar y región mental. Los tumores presentaban un tamaño medio de $19,7 \mathrm{~mm}$. Todas las lesiones se trataron mediante excisión quirúrgica simple y no hubo evidencia de recurrencia o metástasis en ninguno de los casos. ${ }^{8}$

El hecho de que algunos de los casos descritos de TFS, presenten antecedentes de traumatismo en la zona de aparición del tumor, hace que pueda considerarse a los traumatismos como un agente etiológico. ${ }^{3,8}$ En el caso presentado, el paciente refiere como posible agente causal, la exodoncia de un molar adyacente a la lesión.

Aunque se han descrito manifestaciones sistémicas (fiebre, dolor torácico, hipoglucemia y osteoartropatía) asociadas a tumores fibrosos solitarios de gran tamaño, estas manifestaciones no han aparecido en casos intraorales. ${ }^{2-4}$

Histologicamente el TFS suele presentar áreas de una celularidad aumentada y un patrón proliferativo dispuesto al azar, mientras otras regiones presentan figuras mitóticas aisladas. ${ }^{8}$ La celularidad del TFS suele variar de un lugar a otro y está inversamente relacionada con la cantidad de colágeno. 1,8 Entre los hallazgos más comunes en el TFS están: regiones hipercelulares, patrón vascular similar al del hemangioperocitoma y apariencia ondulada parecida a la nerviosa. 8,12

Inmunohistoquimicamente, independientemente de la localización anatómica, la mayoría de los TFS tienen una difusa positividad, de moderada a fuerte para: CD34, bcl2, CD99 y vimentina; mientras que el factor XIIla, (aunque positivo en la mayoría de los casos), aparece en un pequeño porcentaje de células neoplásicas. ${ }^{2-4}$ Además, la mayoría presentan negatividad para: S-100, actina de músculo liso, desmina, factor VIII, antígeno músculo específico, citoqueratina, antígeno de membrana epitelial y CD68.23,3, 610 El caso clínico presentaba una positividad intensa para: vimentina, CD34 y bcl2; una débil positividad para: factor XIlla y actina músculo específica (1A4); y era negativo para: proteina S-100, citoqueratinas (CAM 5,2;AE1-3), desmina y actina muscular (HHF35).

Debido a la gran variedad histológica e inmunohistoquímica que se ve en el TFS, se ha de diferenciar a esta neoplasia de muchos tumores benignos y malignos de partes blandas como el histiocitoma fibroso benigno o maligno, neurofibroma, neurilemoma, miofibroma, leiomioma, fibroma, lipoma de células fusiformes, dermatofibrosarcoma protuberans, angiofibroma de células gigantes, sarcoma sinovial monofásico, siendo el hemangiopericitoma probablemente el tumor con el que es más difícil realizar el diagnóstico diferencial.2-6,11,12,14 El perfil inmunohistoquímico puede ser útil en casos donde las diferencias morfológicas no son claras como con neurilemomas, neurofibromas, tumores periféricos de la vaina neural, angioleiomiomas y miofibromas solitarios. En el caso del histiocitoma fibroso un estudio exhaustivo histológico es suficiente para realizar el diagnóstico diferencial. Las características citológicas malignas también contribuyen a descartar el leiomiosarcoma y el fibrosarcoma. ${ }^{1}$

Aunque todos los casos descritos de TFS intraorales han tenido un comportamiento clínico e histológico benigno, se han descrito variantes atípicas y malignas en la pleura y en otras localizaciones extrapleurales. $2,3,13$ Se estima que entre un 5 y un $20 \%$ de los TFS pleurales se comportan de una manera maligna, caracterizándose por su agresividad local, recurrencia, propagación y la aparición de metástasis a distancia. Revisiones de TFS extratorácicos han demostrado que un $10 \%$ de éstos, incluidos los de partes blandas, pue- ferent tissues and organs, including the connective tissue of the oral mucosa. ${ }^{1,3}$ These primitive mesenchymal cells can function as antigen-presenting cells or intervene in tissue repair. ${ }^{1}$

Shimoyama et al. ${ }^{8}$ reviewed all the cases of oral SFT published in English and Japanese language journals up until 2002 and compiled only 47 cases. The mean age of patients was 51 years and women were predominant (30:18). The cheek was the predominant area of involvement, followed, in decreasing order, by the tongue, gums, palate, lip, vestibular sulcus, retromolar trigone, and mental region. Tumors had a mean size of $19.7 \mathrm{~mm}$. All lesions were treated by simple surgical resection and there was no evidence of recurrence or metastasis in any case. ${ }^{8}$

The fact that some cases of SFT reported had a history of trauma in the area where the tumor later appeared means that trauma can be considered an etiological agent.,8 In the case presented here, the patient referred extraction of a molar adjacent to the tumor as a possible causal agent.

Although systemic manifestations (fever, chest pain, hypoglycemia, and osteoarthropathy) associated with large solitary fibrous tumors have been reported, these manifestations have not been reported in intraoral cases. ${ }^{2-4}$

Histologically, SFT usually presents areas of increased cellularity and a randomly arrayed proliferative pattern, whereas other regions present isolated mitotic figures. ${ }^{8}$ The cellularity of SFT usually varies from one site to another and is inversely related to the amount of collagen. ${ }^{1,8}$ Among the most common findings in SFT are hypercellular regions, a vascular pattern similar to that of hemangiopericytoma, and a wavy, nervoid appearance. 8,12

Immunohistochemically, most SFTs, independently of anatomic location, exhibit diffuse, moderate-to-strong positivity for CD34, bcl2, CD99, and vimentin. Factor XIIIa (although positive in most cases) appears in a small percentage of neoplastic cells. ${ }^{2-4}$ In addition, the majority of SFTs are negative for S-100, smooth-muscle actin, desmin, factor VIII, muscle-specific antigen, cytokeratin, epithelial membrane antigen, and $C D 68.2,3,6,10$ The present clinical case exhibited intense positivity for vimentin, $C D 34$, and bcl2; weak positivity for factor XIIIa and muscle-specific actin (1A4); and negativity for S-100 protein, cytokeratins (CAM 5,2; AE1-3), desmin, and muscular actin (HHF35).

Due to the wide histologic and immunohistochemical variety observed in SFT, this neoplasm must be differentiated from many benign and malignant soft-tissue tumors, such as benign or malignant fibrous histiocytoma, neurofibroma, neurilemmoma, myofibroma, leiomyoma, fibroma, spindle-cell lipoma, dermatofibrosarcoma protuberans, giantcell angiofibroma, and single-phase synovial sarcoma. The differential diagnosis with hemangiopericytoma is probably the most difficult.2-6,11,12,14 The immunohistochemical profile may be useful in cases where morphologic differences are not clear, such as with neurilemmoma, neurofibroma, peripheral neural-sheath tumor, angioleiomyoma, and solitary 
den tener un comportamiento maligno. ${ }^{3}$ No hay unificación de criterios histológicos que determinen un comportamiento clínico maligno del TFS. Los hallazgos histológicos atípicos incluyen: atipia nuclear, hipercelularidad, número de mitosis $>4$ por 10 campos de gran aumento, necrosis y falta de circunscripción. ${ }^{2-4,11}$ Debido a que la presencia de atipias histológicas no predicen un comportamiento clínico agresivo, y a que incluso tumores con características histológicas benignas pueden comportarse de una manera agresiva, se ha sugerido que tanto las imágenes morfológicas como el patrón de crecimiento clínico tienen que considerarse a la hora de clasificar a estos tumores. El TFS en cabeza y cuello no suele comportarse de manera agresiva, aunque hay casos descritos que presentan una alta celularidad y una alta actividad mitótica. ${ }^{1,4}$

El tratamiento de elección consiste en la resección quirúrgica de la lesión. 1,3,4,6,8,10-12 Previamente a la cirugía, se puede realizar una embolización selectiva de los vasos del tumor. ${ }^{10}$ Además se ha utilizado la quimioterapia neoadyuvante (adriamicina y dacarbazina) y la radioterapia postoperatoria, en casos de tumores de gran tamaño con márgenes de resección afectos tras la cirugía.4,11

Debido a la posibilidad de aparición de recurrencias y metástasis tardías, se recomienda un seguimiento a largo plazo de todos los pacientes intervenidos de un TFS, independientemente de la localización anatómica del tumor. ${ }^{2-4,9-11}$

\section{Bibliografía}

1. Veltrini VC, Etges A, Magalhaes MHCG, de Araújo NS, de Araújo VC. Solitary fibrous tumor of the oral mucosa--morphological and immunohistochemical profile in the differential diagnosis with hemangiopericytoma. Oral Oncol 2003;39:420-6.

2. El-Sayed IH, Eisele DW, Yang TL, lezza G. Solitary fibrous tumor of the retropharynx causing obstructive sleep apnea. Am J Otolaryngol 2006;27:259-62.

3. Alawi F, Stratton D, Freedman PD. Solitary fibrous tumor of the oral soft tissues: a clinicopathologic and immunohistochemical study of 16 cases. Am / Surg Pathol 2001;25:900-10.

4. Shnayder Y, Greenfield B], Oweity T, DeLacure MD. Malignant solitary fibrous tumor of the tongue. Am J Otolaryngol 2003;24:246-9.

5. Hirano M, Tanuma J, Shimoda T, Sugihara K, Tsuneyoshi M, Kitano M. Solitary fibrous tumor in the mental region. Pathol Int 2001;51:905-8.

6. Harada T, Matsuda H, Maruyama R, Yoshimura Y. Solitary fibrous tumours of the lower gingiva: a case report. Int J Oral Maxillofac Surg 2002;31:448-50.

7. Klemperer $P$, Rabin CB. Primary neoplasms of the pleura: a report of five cases. Arch Pathol 1931;11:385-412.

8. Shimoyama T, Horie N, Ide F. Solitary fibrous tumor of the palate: a case report and review of the literature. J Oral Maxillofac Surg 2004;62:895-7.

9. Sato J, Asakura K, Yokoyama Y, Satoh M. Solitary fibrous tumor of the parotid gland extending to the parapharyngeal space. Eur Arch Otorhinolaryngol 1998; 255:18-21.

10. Yamashita Y, Satoh T, Goto M. Solitary fibrous tumor of the tongue: a case report with immunohistochemical studies. Int J Oral Maxillofac Surg 2002;31:681-3.

11. Suarez Roa ML, Ruíz Godoy Rivera LM, Meneses García A, Granados García M, Mosqueda Taylor A. Tumor fibroso solitario de la región parotídea. Reporte de un caso y revisión de la literatura. Med Oral 2004;9:82-8.

12. Kuo WP, Sirois DA, Pemble CW. Locally aggressive solitary fibrous tumor in the infraorbital region: a case report and review of the literatura. Oral Surg Oral Med Oral Pathol Oral Radiol Endod 2001;92:308-11.

13. Suhr M, Gottschalk J, Kreusch T. Metastatic malignant solitary fibrous tumour to the infra-temporal fossa. Int J Oral Maxillofac Surg 2003;32:659-61.

14. García de Marcos JA, Dean Ferrer A, Alamillos Granados F, Ruíz Masera JJ, Barrios Sánchez G, Vidal Jiménez A. Sarcoma sinovial, monofásico fusocelular, cervical. Rev Esp Cir Oral Maxilofac 2005;27:381-7. myofibroma. In the case of fibrous histiocytoma, an exhaustive histologic study suffices to establish the differential diagnosis. Malignant cytological features also help to rule out leiomyosarcoma and fibrosarcoma. ${ }^{1}$

Although all the cases of intraoral SFT reported have had a benign clinical and histologic behavior, atypical and malignant variants have been described in pleural and extrapleural locations. 2,3,13 It is estimated that $5 \%$ to $20 \%$ of pleural SFTs behave malignantly, with local aggressiveness, recurrence, propagation, and distant metastases. Reviews of extrathoracic SFTs have demonstrated that $10 \%$ of these tumors, including soft-tissue tumors, may have a malignant behavior. ${ }^{3}$ Consensus is lacking on the histologic criteria that define malignant clinical behavior in SFT. Atypical histologic findings include nuclear atypia, hypercellularity, mitotic figures $>4$ per 10 high-power fields, necrosis, and absence of defined margins. ${ }^{2-4,11}$ As the presence of histologic atypia does not predict aggressive clinical behavior, because even tumors with benign histologic characteristics can behave aggressively, it has been suggested that morphologic images and the pattern of clinical growth be considered when classifying these tumors. SFTs of the head and neck usually do not behave aggressively, although cases of high cellularity and high mitotic activity exist. ${ }^{1,4}$

The treatment of choice is surgical tumor resection. 1,3,4,6,8,10-12 Before surgery, selective embolization of the blood vessels of the tumor can be performed. ${ }^{10}$ In addition, neoadjuvant chemotherapy (doxorubicin and dacarbazine) and postoperative irradiation have been used in cases of large tumors with involvement of the resection margins after surgery. 4,11

Because of the possibility of recurrence and late metastasis, long-term follow-up of all patients operated for SFT is advised, regardless of the anatomic location of the tumor..$^{2-4,9-11}$ 